\title{
Effect of Air Velocity and Pre Treatment on Drying Characteristics of Tomato Slices during Solar Tunnel Drying
}

\author{
S.P. Rajkumar, Arun Prasath Venugopal", Aarthy Viswanath and N. Varadharaju \\ Department of Food and Agricultural Process Engineering, PHTC, \\ Tamil Nadu Agricultural University, Coimbatore- 641003, Tamil Nadu, India \\ *Corresponding author
}

\section{A B S T R A C T}

\section{Keywords}

Solar tunnel drying, Drying of tomato slices,

Moisture content, Drying rate.

Article Info

Accepted:

04 May 2017

Available Online:

10 June 2017
A study was conducted for drying of tomatoes in the developed solar drier at three different air velocities of $2 \mathrm{~m} / \mathrm{s}, 3 \mathrm{~m} / \mathrm{s}, 4 \mathrm{~m} / \mathrm{s}$ respectively. The samples were given pre-treatment with $\mathrm{KMS}+\mathrm{CaCl}_{2}$ and $\mathrm{NaCl}$. Open sun drying was carried out simultaneously on the other side and was taken as control. The final moisture content of 7.1 per cent (w.b.) was achieved after drying for 10 hours at the air velocity of $3 \mathrm{~m} / \mathrm{s}$ whereas it was 16.7 per cent (w.b.) and 23.9 per cent (w.b.) at 2 $\mathrm{m} / \mathrm{s}$ and $4 \mathrm{~m} / \mathrm{s}$ respectively. The moisture content of tomato under sun drying was 39.1 per cent (w.b.) at the 10th hour. It was found that samples pre-treated with $\mathrm{KMS}+\mathrm{CaCl}_{2}$ achieved the final moisture content of 7.1 per cent (w.b.) within 10 hours. Samples treated with $\mathrm{KMS}+\mathrm{CaCl}_{2}$ showed a higher drying rate of 1.68 $\mathrm{g} / \mathrm{min}$ and $1.60 \mathrm{~g} / \mathrm{min}$ for $\mathrm{NaCl}$. The untreated sample showed the drying rate of $1.52 \mathrm{~g} / \mathrm{min}$ and the open sun drying method had the minimum drying rate of 1.16 $\mathrm{g} / \mathrm{min}$. It was found that the $\mathrm{KMS}+\mathrm{CaCl}_{2}$ treated samples recorded maximum drying rate at a velocity of $3 \mathrm{~m} / \mathrm{s}$.

\section{Introduction}

Tomato (Lycopersicum esculentum) is one of the most important "protective foods "because of its special nutritive value. In present days, the demand for the tomatoes is increasing steadily with an increase in population and its likeliness towards tomato. India is the 2nd leading tomato producing country occupying 11.2 percent of the world annual production next to China. The total production of tomato in India is about 182.27 lakh tonnes per year and the total export quantity of tomato from India is about 343 tonnes. Sun drying is a well-known traditional method of drying agricultural commodities immediately after harvest. However, it is plagued with in-built problems, since the product is unprotected from rain, storm, windborne dirt, dust, and infestation by insects, rodents, and other animals. It may result in physical and structural changes in the product such as shrinkage, case hardening, loss of volatiles and nutrient components and lower water reabsorption during rehydration. Therefore, the quality of sun dried product is degraded and sometimes become not suitable for human consumption. 


\section{Materials and Methods}

\section{Drying chamber}

The triangle frame was covered with UV stabilized semi-transparent polythene sheet of 200 micron thickness. The idea behind the stabilization is to block the sun's UV light and thereby protecting the harness and degradation to the polythene film. The solar radiation transmits through the sheet, which has a transmitivity of 90 percent.

The UV stabilized sheet is transparent to shortwave radiation and opaque to long wave radiation. During day time, the shortwave radiations get entrapped through the polythene sheet thus provides heat inside the dryer. This conversation results in increased temperature inside the dryer (Kulanthaisami et al., 2009) and Ibrahim (2008). Doors of 5 $\mathrm{cm}$ height have been provided at the bottom of the drying chamber as shown in figures 1 and 2 .

Duffie and Beckman (1991) suggested that slope of the tunnel should be maintained by subtracting and adding 10o in the latitude of the site for summer and winter. Since our site has latitude of 36o the slope angle of the tunnel was selected as 310 so that it could receive maximum radiations perpendicular to the film.

\section{Variable speed AC fans}

Insufficient airflow can result in slow moisture removal as well as high dryer temperatures (Augustus et al., 2002). The air velocity (more than $1 \mathrm{~ms}^{-1}$ ) is required as suggested by Anjum et al., (2013) for solar tunnel dryer - Hohenheim design. Three variable speed $\mathrm{AC}$ fans of $15 \mathrm{~cm}$ diameter with power consumption $0.50 \mathrm{~kW}$ were fitted at the front side of the solar dryer so as to pass the air uniformly in the drying chamber. The other side of the dryer was provided with ventilation to remove moist air Gauhar et al., (2011).

\section{Measurement of temperature and RH} inside the dryer

The temperature and relative humidity sensor was used for the experiment (Make - Omega, OM-43 series). The data logger was fixed in the dryer for measuring the temperature and $\mathrm{RH}$ for the defined period of time. After the completion of the experiment, the data logger was connected to the computer interface cable and the data was displayed in the graphical form. Anemometer of model AM-4201 was used to determine the velocity of air while performing the drying experiment the anemometer was placed inside the dryer and the readings were recorded.

\section{Results and Discussion}

\section{Drying characteristics of tomato}

Tomato slices were dried in the developed solar drier at three different air velocities of 2 $\mathrm{m} / \mathrm{s}, 3 \mathrm{~m} / \mathrm{s}, 4 \mathrm{~m} / \mathrm{s}$ respectively. The samples were given pre-treatment with $\mathrm{KMS}+\mathrm{CaCl}_{2}$ and $\mathrm{NaCl}$. Open sun drying was also carried out simultaneously and was taken as control.

\section{Effect of air velocity and pre-treatment methods on moisture reduction}

The moisture reduction during drying of tomato slices inside the solar dryer at the air velocity of $3 \mathrm{~m} / \mathrm{s}$ with different pre-treatment methods such as $\mathrm{KMS}+\mathrm{CaCl}_{2}$ and $\mathrm{NaCl}$ is shown in figure 3 . The drying experiment was carried out with the tomato slices of initial moisture content of 91.9 per cent (w.b.) where it was reduced to a final moisture content of 7.1 per cent (w.b.). The time taken to reach the final moisture of 7.1 per cent (w.b.) was 10 hours for the samples treated with 
$\mathrm{KMS}+\mathrm{CaCl}_{2}$. From figure 4 it is observed that the samples pre-treated with $\mathrm{KMS}+\mathrm{CaCl}_{2}$ showed increasing moisture removal than the samples treated with $\mathrm{NaCl}$. At 10 hours of drying the moisture content of tomato was 11.4 per cent (w.b.) for $\mathrm{NaCl}$ and 18.4 percent (w.b.) for sample having no treatment. From figure 4 , it is observed that rate of moisture removal was found higher in the tomato slices treated with $\mathrm{KMS}+\mathrm{CaCl}_{2}$ and $\mathrm{NaCl}$ compared to the untreated samples.

The final moisture content of the product dried at the air velocity of $2 \mathrm{~m} / \mathrm{s}$ was higher at 26.8 per cent (w.b) in 10 hours of drying whereas it was 7.1 per cent (w.b.) in case of 3 $\mathrm{m} / \mathrm{s}$. This was due to the insufficient air circulation inside the dryer at air velocity of 2 $\mathrm{m} / \mathrm{s}$ and this reduced the removal of moist air from the drying chamber. Also the incoming heated air could not sufficiently replace the moist rich air to pick up more amount of moisture from the product. This resulted in lesser reduction of moisture content in the tomato slices. At the same time, during drying of tomatoes inside the solar dryer at the air velocity of $4 \mathrm{~m} / \mathrm{s}$ showed poor rate of moisture reduction when compared to the other two velocities.

The effect of air velocity at $4 \mathrm{~m} / \mathrm{s}$ on moisture reduction is shown in figure 5. It was observed that the moisture reduction was less when compared to the other two air velocities. The pre-treated samples showed slightly higher reduction in moisture content than the untreated samples. Due to the higher velocity of air inside the solar dryer, the incoming air was not heated much and it does not become relatively dry. Since the air not attained the higher temperature, it was not expanded to pick up moisture from the product resulting in a slow moisture reduction. The open sun drying method showed very less rate of moisture reduction compared to the solar drying method which is shown in figure 6.

Fig.1 Arrangement of trays inside the drying chamber

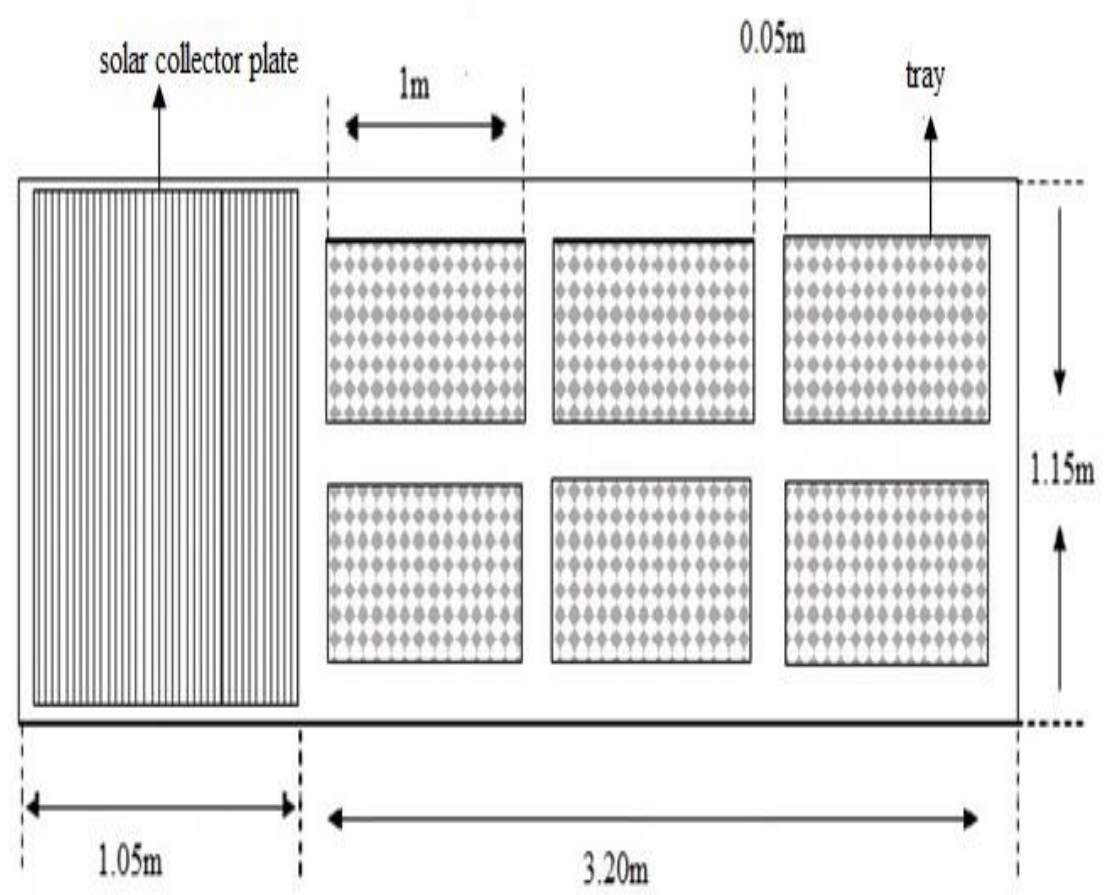


Fig.2 Developed Solar Tunnel Dryer

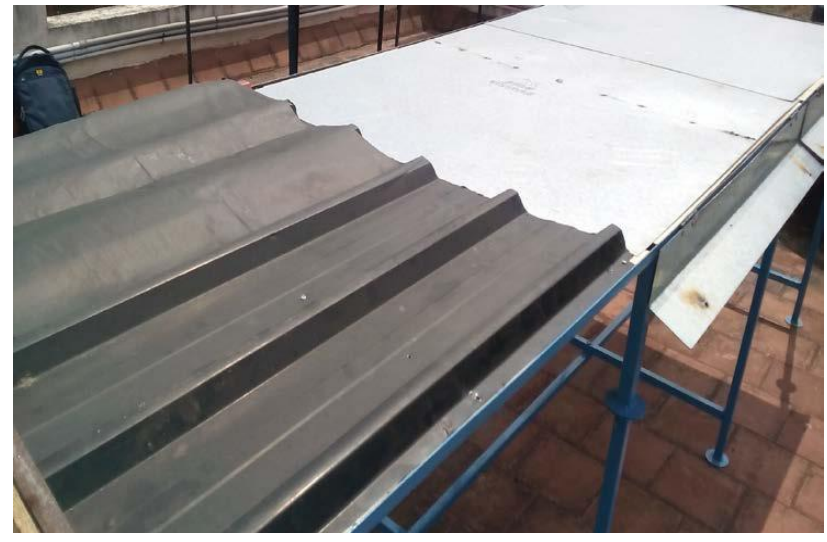

Pre-heater section

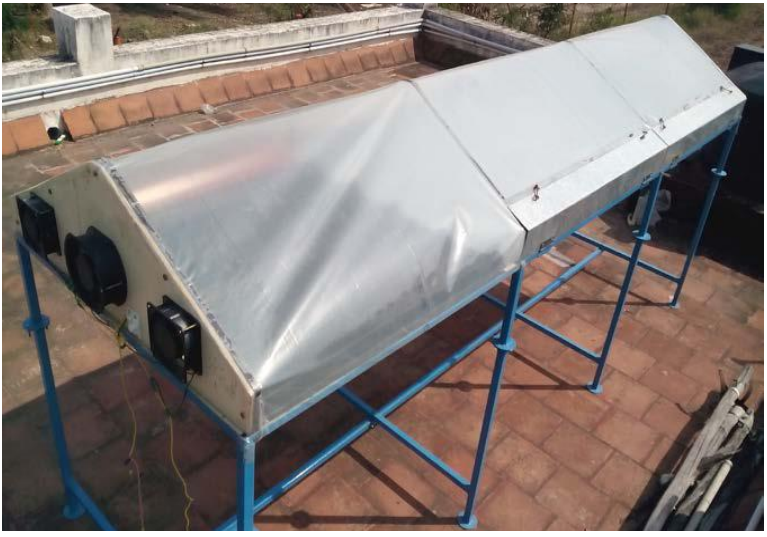

Isometric view of the solar dryer

Fig.3 Effect of air velocity on moisture reduction

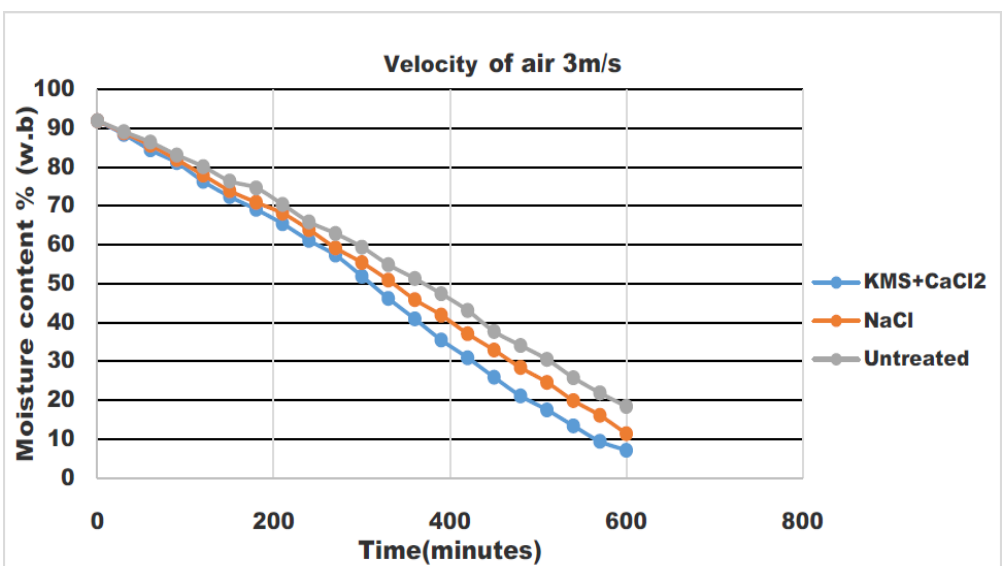

Fig.4 Effect of air velocity on moisture reduction

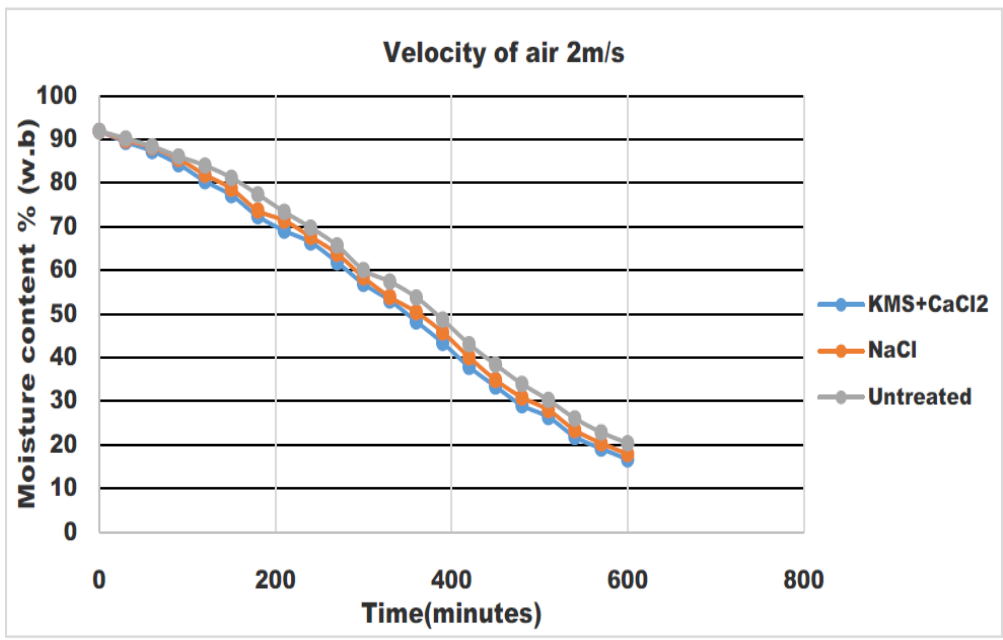


Fig.5 Effect of air velocity on moisture reduction

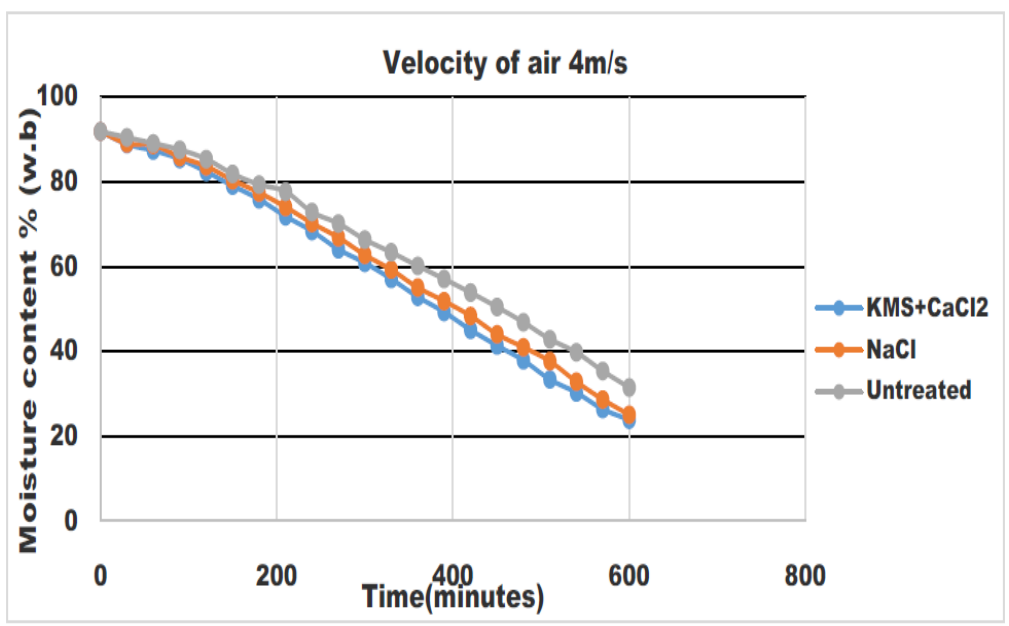

Fig.6 Moisture reduction during open sun drying of tomatoes

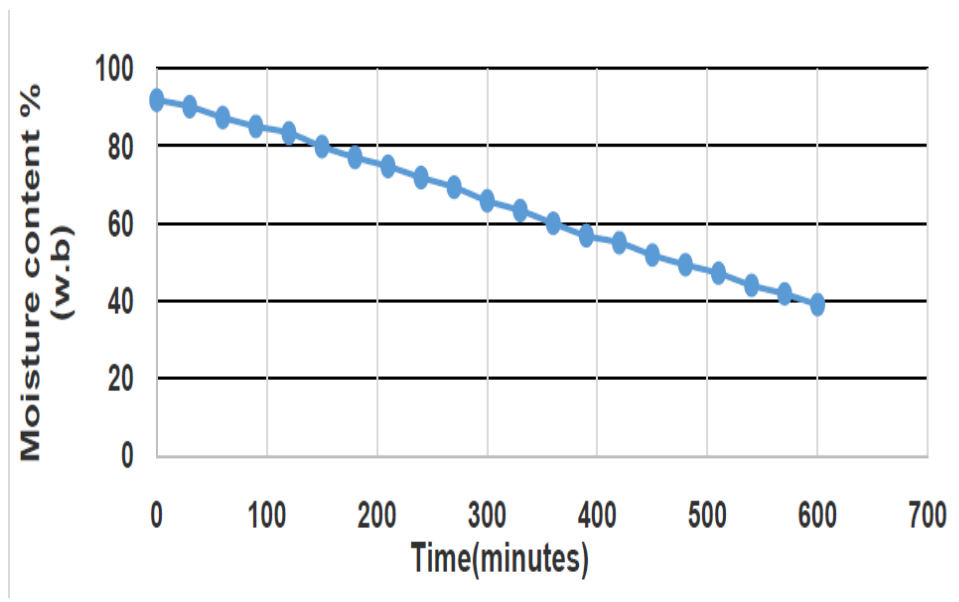

Fig.7 Effect of $2 \mathrm{~m} / \mathrm{s}$ air velocity and pre-treatment methods on rate of drying

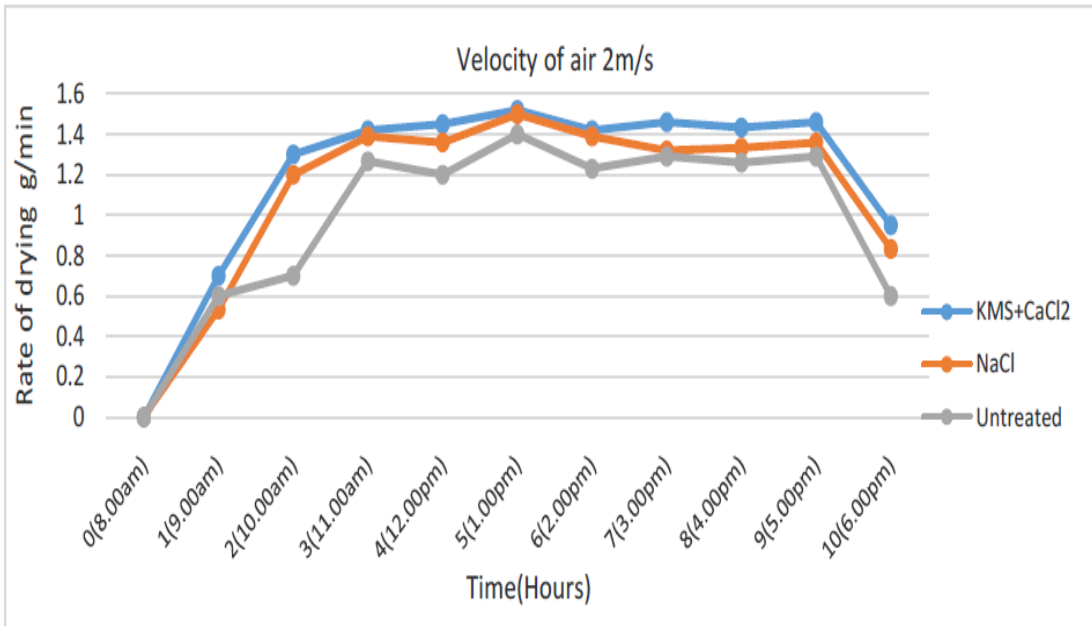


Fig.8 Effect of $3 \mathrm{~m} / \mathrm{s}$ air velocity and pre-treatment methods on rate of drying

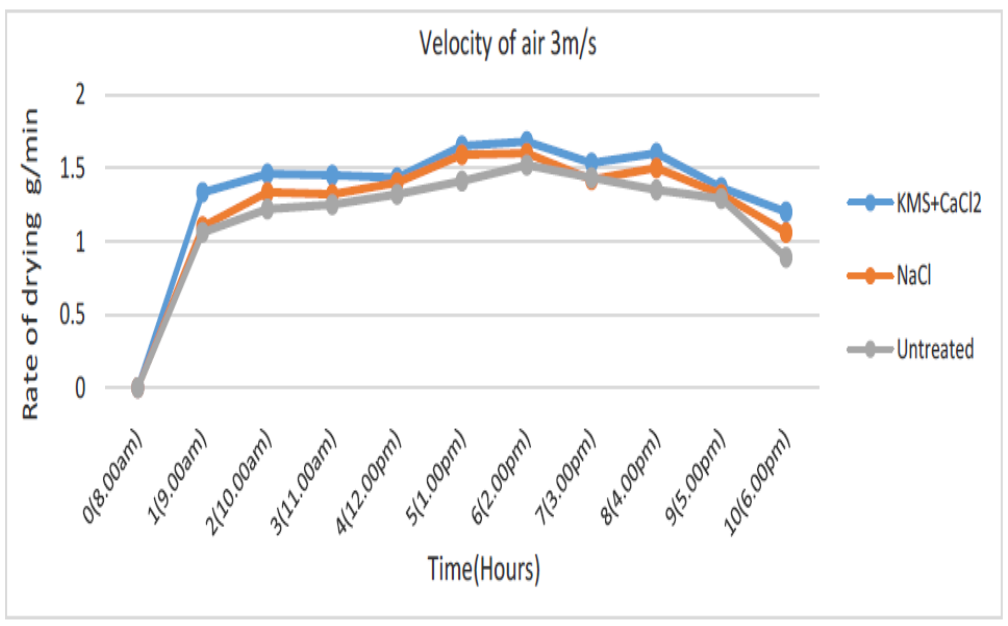

Fig.9 Effect of $4 \mathrm{~m} / \mathrm{s}$ air velocity and pre-treatment methods on rate of drying

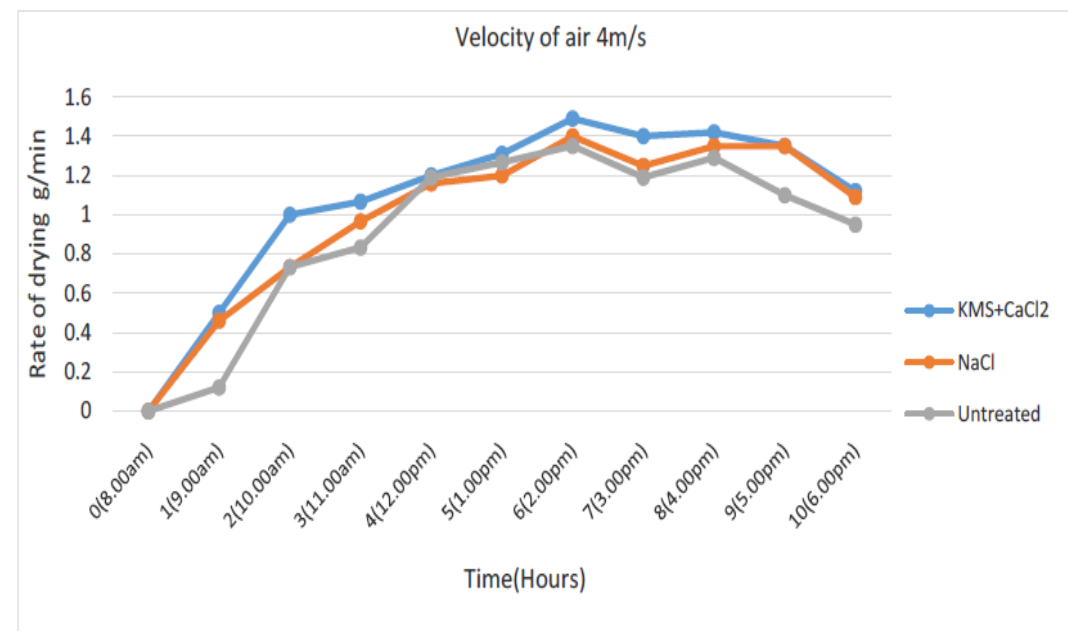

Fig.10 Effect of open sun drying method on rate of drying

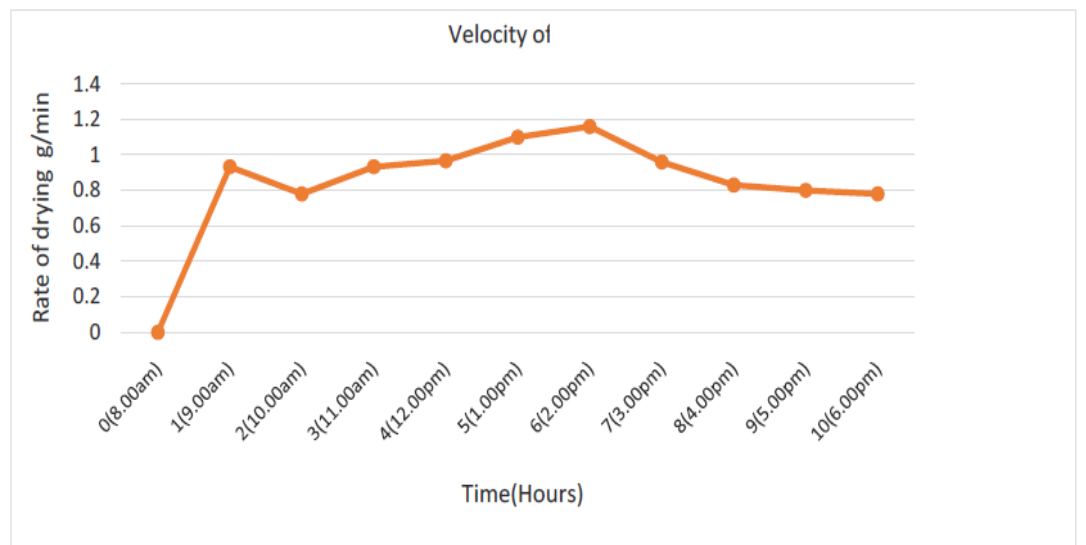


Effect of air velocity and pre-treatment methods on rate of drying

Drying rate was more at 2 p.m. in the air velocity of $3 \mathrm{~m} / \mathrm{s}$ which was $1.68 \mathrm{~g} / \mathrm{min}$ for the samples pre-treated with $\mathrm{CaCl}_{2}+\mathrm{KMS}$ and for $\mathrm{NaCl}$ treated samples it was $1.60 \mathrm{~g} / \mathrm{min}$. The untreated sample showed the drying rate of $1.52 \mathrm{~g} / \mathrm{min}$ at $2-2.30 \mathrm{p} . \mathrm{m}$. since the drying temperature was maximum at that time and also the solar intensity was maximum.

From the results it was observed that $\mathrm{CaCl}_{2}+$ KMS treated samples showed the higher rate of drying. Since the fruit was cut into slices, the open form of the tissue when treated with calcium tends to bind with the tissue and facilitated moisture mobility. Similar results were reported by Mohseni et al., (2011) and Hossain et al., (2008).

The samples pre-treated with $\mathrm{KMS}+\mathrm{CaCl}_{2}$ and solar dried at $2 \mathrm{~m} / \mathrm{s}$ and $4 \mathrm{~m} / \mathrm{s}$ showed the drying rate of $1.52 \mathrm{~g} / \mathrm{min}$ and $1.49 \mathrm{~g} / \mathrm{min}$ respectively. The samples treated with $\mathrm{NaCl}$ showed less drying rates than the samples treated with $\mathrm{KMS}+\mathrm{CaCl}_{2}$. But both the treated samples showed higher rate of drying than the untreated samples at all the three air velocities. The increase of the drying potential and the reduction of the drying time can be explained by the fact that the rise of temperature causes an increase of the heat transfer intensity.

The moisture content decreases with the drying temperature and higher air velocities which can offer big deficit to the water vapour pressure is one of the driving forces for the diffusion process of moisture to the outside. Similar results were reported by Mariem et al., (2014). The variation in rate of drying with respect to different air velocity is presented in figures $7,8,9$, and variation in rate of drying during open sun drying is presented in figure 10. It was observed that the open sun drying method showed a maximum drying rate of $1.16 \mathrm{~g} / \mathrm{min}$ at 6 th hour i.e. 2 p.m. which was less compared to the solar drying method. Since the maximum drying temperature was $33.9^{\circ} \mathrm{C}$ which was less compared to the temperature inside the solar dryer, the rate of drying was minimum in open sun drying.

In conclusion, the tomatoes were dried inside the solar dryer from morning 8.00 a.m to evening 6.00 p.m with an initial moisture content of 91 per cent (w.b.). The maximum temperature of $59.4^{\circ} \mathrm{C}$ was recorded at 2.00 $\mathrm{pm}$ inside the solar dryer at the air velocity of $3 \mathrm{~m} / \mathrm{s}$ and $56.2^{\circ} \mathrm{C}$ and $52.3^{\circ} \mathrm{C}$ at $2 \mathrm{~m} / \mathrm{s}$ and 3 $\mathrm{m} / \mathrm{s}$ respectively. The optimum temperature in the range $50-60^{\circ} \mathrm{C}$ was maintained for about 3 hours at a velocity of $3 \mathrm{~m} / \mathrm{s}$.

The relative humidity inside the dryer was found to be 26.2 per cent at the air velocity of $3 \mathrm{~m} / \mathrm{s}$. The relative humidity inside the dryer at an air velocity of $2 \mathrm{~m} / \mathrm{s}$ was 33.2 per cent and this was due to the insufficient air flow to remove the moist air from the dryer. The air velocity of $3 \mathrm{~m} / \mathrm{s}$ was found to be optimum for this dryer.

The final moisture content of 7.1 per cent (w.b.) was achieved after drying for 10 hours at the air velocity of $3 \mathrm{~m} / \mathrm{s}$ whereas it was 16.7 per cent (w.b.) and 23.9 per cent (w.b.) at $2 \mathrm{~m} / \mathrm{s}$ and $4 \mathrm{~m} / \mathrm{s}$ respectively. The moisture content of tomato under sun drying was 39.1 per cent (w.b.) at the 10th hour. It was found that samples pre-treated with $\mathrm{KMS}+\mathrm{CaCl}_{2}$ achieved the final moisture content of 7.1 per cent (w.b.) within 10 hours.

Samples treated with $\mathrm{KMS}+\mathrm{CaCl}_{2}$ showed a higher drying rate of $1.68 \mathrm{~g} / \mathrm{min}$ and 1.60 $\mathrm{g} / \mathrm{min}$ for $\mathrm{NaCl}$. The untreated sample showed the drying rate of $1.52 \mathrm{~g} / \mathrm{min}$ and the open sun drying method had the minimum drying rate of $1.16 \mathrm{~g} / \mathrm{min}$. It was found that the 
$\mathrm{KMS}+\mathrm{CaCl}_{2}$ treated samples recorded maximum drying rate at a velocity of $3 \mathrm{~m} / \mathrm{s}$.

\section{References}

Augustus, M., S. Kumar and S.C. Bhattacharya. 2002. A comprehensive procedure for performance evaluation of solar food dryers. Renewable and Sustainable Energy Reviews. 6: 367393.

Anjum, M., U. Sultan and M. Iqbal. 2013. Development And Performance Evaluation of A Locally Fabricated Portable Solar Tunnel Dryer For Drying of Fruits. Vegetables and Medicinal Plants. Pakistan Journal of Agricultural Science. 50(3): 493-498.

Duffie, J.A. and W.A. Beckman. 1991. Solar engineering of thermal processes, 2nd Ed. Wiley Interscience, New York, USA.

Gauhar, A., S. Kumar and V. Gnanaranjan. 2011. Optimization of fan speed in a forced convective solar dryer. Renewable Energy. 5: 16 - 20.

Hossain, M. A., B. M. A. Amer and K. Gottschalk. 2008. Drying characteristics of tomato slices under forced air oven. Journal of Food Science and Technology. 9: $56-85$.

Ibrahim, D. 2008. Air drying characteristics of tomatoes. Journal of Food Engineering. 77: 478-485.

Kulanthaisami, S., P. Subramanian, R. Mahendiran, P. Venkatachalam and A. Sampathrajan. 2009. Drying Characteristics of Coconut in Solar Tunnel Dryer. Madras Agricultural Journal.96 (1-6): 265-269.

Mariem, S.B., B. Mabrouk and M. Khan. 2014. Drying Characteristics of Tomato Slices and Mathematical Modeling. International Journal of Energy Engineering. 4: 17-24.

\section{How to cite this article:}

Rajkumar, S.P., Arun Prasath Venugopa, Aarthy Viswanath and Varadharaju, N. 2017. Effect of Air Velocity and Pre Treatment on Drying Characteristics of Tomato Slices during Solar Tunnel Drying. Int.J.Curr.Microbiol.App.Sci. 6(6): 573-580. doi: https://doi.org/10.20546/ijcmas.2017.606.067 